\title{
Urgences
}

\section{... Et le paradis à la fin de nos écritures !}

\section{Gilbert Dupuis}

Numéro 6, 4e trimestre 1982

URI : https://id.erudit.org/iderudit/025086ar

DOI : https://doi.org/10.7202/025086ar

Aller au sommaire du numéro

Éditeur(s)

Urgences

ISSN

0226-9554 (imprimé)

1927-3924 (numérique)

Découvrir la revue

Citer ce document

Dupuis, G. (1982).... Et le paradis à la fin de nos écritures ! Urgences, (6), 5-6.

https://doi.org/10.7202/025086ar d'utilisation que vous pouvez consulter en ligne.

https://apropos.erudit.org/fr/usagers/politique-dutilisation/ 


\section{...et le paradis à la fin de nos écritures!}

Opération URGENCES neige! Ce sixième wagon gris acier ouvre I'hiver à un train d'auteurs en quête d'enfance, de chaleur et de transports... Huit écriveux racontent les paysages qui défilent devant leurs yeux et derrière leur front.

Écrire. Tenter de réaliser le miracle de la coïncidence des univers mobiles. Chercher la correspondance et la faire pour la trouver. Par la première fenêtre, Richard Corriveau salue le vieux frère et tous les mutants. Des gestes frénétiques comme à quelqu'un sur le point de le voir. II agite des lettres fraîchement écrites où il est dit "qu'il y a de la glace à casser" et que "les actes crient eux aussi plus sûrs encore que la rime".

Susane Hurtubise monologue au second carreau pour elle-même et pour sa mère. Elle déroule "une longue plainte envahissante qui exagère" et dit que "I'enfance est restée prisonnière dans les griffes de la peur".

En troisième lieu, Christine Bernard relate une histoire de gardiennage où le quotidien cache mal d'étranges grimaces.

"Dans quel pays étrange mon âme voyage-t-elle en ce moment?" s'interroge Sonya Anguelova. De la quatrième fenêtre, elle parle "des pays aux pages blanches où des mots bâtissent des musiques d'anges" et surtout veut savoir "si on peut désirer la mort quand on a juste cinq ans?"

Mais l'enfant lui "se pique au jeu dans la neige anniversaire sans rougir trop des froidures sous sa casquette de fiction". Dans la suivante séquence, je propose ma contribution en douze gros plans sur l'enfan$\mathrm{ce}$ - miroir et la correspondance magique avec $\mathrm{Ni}$ colas-du-grabuge-au-coeur. 
Marie-Andrée Massicotte adoucit ses accents pour nous faire croire que "I'hiver, dans les grandes poudreries, les épinettes courbaient la tête pour voir si le feu dans le poêle était bien pris". Des mots de soie verte et d'éclats marins habitent des phrases clins d'oeil où "la vie attend d'être gagnée".

Ensuite viennent les images et les évocations de Andréa Moorhead. "Matin de givre, des feuilles orange, (...), sang des os (...) étincelle de joie". Une respiration particulière dans le paysage.

Au dernier carreau de ce sixième wagon, Michel Savard affiche les "conditions du contrat". Des plaques descriptives à la queue leu leu pour dire "que chantent les enfants puis se plaignent de la longueur du trajet" et que "le transporteur peut être remplacé" et que "dehors les érables coulent".

Nous proposons cette livraison d'URGENCES à tous les fêtards littéraires; nous leur souhaitons une bien bonne année... et le paradis du début à la fin de nos écritures!

Gilbert Dupuis pour le Comité de direction 